\title{
PENGEMBANGAN MEDIA PEMBELAJARAN MATEMATIKA SISWA SMP BERBASIS ANDROID
}

\author{
Siti Komariah ${ }^{1}$, Huri Suhendri ${ }^{2}$, dan Arif Rahman Hakim ${ }^{3}$ \\ ${ }^{1}$ Depok Jawa Barat, ${ }^{2,3}$ Program Studi Pendidikan Matematika Universitas Indraprasta PGRI Jakarta
}

\section{INFO ARTICLES}

Article History:

Received: 06-09-2018

Revised: 20-10-2018

Approved: 02-12-208

Publish Online: 30-12-2018

Key Words:

Media Learning, Mathematics

\section{(c) ()}

This article is licensed under a Creative Commons AttributionShareAlike 4.0 International License.

\begin{abstract}
This research aims to develop an android-based learning media with software Construct 2 material number for the students of Junior High School classes VII, VIII, and IX. This research use approach to research and development (research and development) with the ADDIE model of development: (1) analysis (analysis), including: needs analysis, analysis of the characteristics of the students, and curriculum analysis, (2) design ( the design), include: the creation of flowcharts, storyboards, interface design, and (3) development (development), include: the collection of material, product creation and revision, (4) implementation (implementation), in this case the researchers don't do stage implementation because of lack of time, (5) evaluation (evaluation), include the following: assessment by the expert question form material, media quality assessment now learning by the media, and now experts design development. Based on the assessment carried out by the experts, it can be concluded that the design of learning mathematics.
\end{abstract}

\begin{abstract}
Abstrak: Penelitian ini bertujuan untuk mengembangkan media pembelajaran berbasis android dengan software Construct 2 pada materi bilangan untuk siswa SMP kelas VII, VIII, dan IX. Penelitian ini menggunakan pendekatan penelitian dan pengembangan (research and development) dengan model pengembangan ADDIE yaitu: (1) analysis (analisis), meliputi: analisis kebutuhan, analisis karakteristik siswa, dan analisis kurikulum, (2) design (perancangan), meliputi: pembuatan flowchart, storyboard, dan desain antarmuka, (3) development (pengembangan), meliputi: pengumpulan materi, pembuatan produk dan revisi, (4) implementation (implementasi), dalam hal ini peneliti tidak melakukan tahap implementasi karena keterbatasan waktu, (5) evaluation (evaluasi), meliputi: angket penilaian oleh ahli materi, angket penilaian kualitas media pembelajaran oleh ahli media, dan angket ahli desain pengembangan. Berdasarkan penilaian yang dilakukan oleh para ahli tersebut, dapat disimpulkan bahwa desain pembelajaran matematika tingkat SMP dengan software Construct 2 berbasis android mendapat nilai para ahli materi berupa persentase yaitu sebesar $85,3 \%$, ahli media $80 \%$, dan ahli desain pengembangan 93\% sehingga dapat dikategorikan sangat baik dan telah memenuhi kualifikasi valid. Dengan kata lain, media yang dikembangkan dalam penelitian ini dinilai layak dan sangat baik untuk digunakan dalam pembelajaran matematika.
\end{abstract}

Correspondence Address: Depok, Jawa Barat, Indonesia; e-mail: komariah28@ gmail.com

How to Cite (APA $6^{\text {th }}$ Style): Komariah, dkk. (2018). Pengembangan Media Pembelajaran Matematika Siswa SMP Berbasis Android.. JKPM (Jurnal Kajian Pendidikan Matematika), Vol 4(1), 43-52

Copyright: Komariah, dkk, (2018)

Competing Interests Disclosures: The authors declare that they have no significant competing financial, professional or personal interests that might have influenced the performance or presentation of the work described in this manuscript. 


\section{PENDAHULUAN}

Pendidikan adalah upaya dalam mengembangkan suatu kualitas sumber daya manusia dengan terarah dan menyeluruh oleh seluruh generasi bangsa agar dapat berkembang secara optimal dengan dukungan berbagai pihak. Oleh karena itu, perkembangan pendidikan sebaiknnya sejalan dengan proses perubahan kehidupan. Perubahan yang dapat memperbaiki pendidikan pada semua tingkat, dalam mengantisipasi perubahan di masa mendatang. Pendidikan yang mampu mendukung pembangunan di masa mendatang adalah pendidikan yang mampu mengembangkan potensi siswa, sehingga siswa mampu menghadapi dan memecahkan problema kehidupan yang dihadapi. Oleh sebab itu, untuk meningkatkan kualitas pendidikan yang lebih baik dalam keberhasilan pencapaian tujuan pendidikan, perlu adanya persiapan yang dapat menunjang kemampuan setiap individu agar dapat mengembangkan ilmu pengetahuan dan memiliki batasan yang jelas karena pendidikan merupakan suatu hal yang penting bagi setiap manusia. Siswa merupakan komponen penting dalam sebuah pendidikan. Pada tingkat pendidikan dasar dan menengah, matematika dimasukkan dalam kelompok dasar yang harus dikuasai siswa. Karena pentingnya matematika pada jenjang pendidikan dasar dan menengah tersebut, mata pelajaran matematika menempati urutan pertama dalam hal jumlah jam pelajaran.

Matematika merupakan salah satu mata pelajaran penting yang dipelajari pada semua jenjang pendidikan. Menurut Supardi (2013:82) "Matematika adalah ilmu pengetahuan eksak yang berhubungan dengan logika, penalaran, bilangan, operasi perhitungan, konsep-konsep abstrak, serta fakta-fakta kuantitatif berupa hubungan pola pikir bentuk dan ruang, serta dapat menimbulkan suatu pola pikir yang masuk akal dan berguna untuk mengatasi berbagai persoalan dalam kehidupan sehari-hari”. Senada dengan itu, Suhendri (2011:32), mengemukakan bahwa "Matematika adalah ilmu tentang bilangan, bangun, hubungan-hubungan konsep dan logika dengan menggunakan bahasa lambang atau simbol dalam menyelesaikan masalahmasalah dalam kehidupan sehari-hari."

Matematika yang diajarkan pada saat ini dilakukan dengan cara guru mengajarkan rumus dan prosedur. Hal tersebut membuat siswa menjadi kurang termotivasi dan menganggap matematika itu menakutkan serta membosankan karena hanya melihat rumus dan prosedur saja sebagai kegiatan pembelajaran matematika. Untuk itu, diperlukan inovasi dalam pembelajaran matematika agar tidak dipandang lagi sebagai mata pelajaran yang menakutkan dan membosankan melainkan sebagai mata pelajaran asyik dan menyenangkan. Inovasi yang dilakukan misalnya dari segi guru dalam menyampaikan pelajaran yaitu mengenai strategi maupun metode yang digunakan guru dalam pembelajaran matematika.

Guru sebagai pelaku utama proses pembelajaran di kelas merupakan potensi utama perkembangan pendidikan, sebaiknya guru setiap saat harus mengembangkan potensinya dalam rangka meningkatkan kualitas pembelajaran. Begitu banyak cara yang bisa ditempuh untuk meningkatkan kualitas pembelajaran, salah satunya adalah pemanfaatan desain pembelajaran. Huri dan Ema (2016) salah satu hal yang berpengaruh dalam pembelajaran yang efektif adalah desain pembelajaran yang di buat sesuai dengan kebutuhan peserta didik dan dilakukan demi tercapainya tujuan pembelajaran. Oleh karena itu, seorang guru diharapkan mampu membuat bahan pembelajaran yang inovatif dan mampu meningkatkan ketertarikan siswa untuk belajar matematika. Binangun dan Hakim (2016) yang menyatakan bahwa pembelajaran matematika yang dilakukan sesuai dengan kondisi dan kebutuhan siswa, hal ini dimaksudkan untuk menjadikan pembelajaran efektif dan menyenangkan bagi siswa. Salah satu alternatif pembelajaran matematika yang dimaksud yaitu dengan alat bantu berupa alat peraga. Sanjaya (2010:14) menegaskan bahwa seorang guru perlu memiliki kemampuan merancang dan mengimplementasikan berbagai strategi pembelajaran yang dianggap cocok dengan minat dan bakat serta sesuai dengan taraf perkembangan siswa, termasuk didalamnya memanfaatkan berbagai sumber dan media pembelajaran untuk menjamin efektivitas 
pembelajaran. Desain pembelajaran juga dibuat sedemikian rupa agar kegiatan pembelajaran dapat berjalan efektif.

Kecanggihan teknologi informasi saat ini mendorong kita untuk terus mengikuti kemajuannya terutama di bidang telekomunikasi, saat ini alat komunikasi sudah menjadi bagian dari hidup manusia salah satunya smartphone. Smartphone merupakan salah satu alat komunikasi yang sudah mendarah daging di masyarakat, sehingga hampir semua masyarakat menggunakannya. Berdasarkan wawancara dengan salah satu guru matematika, diketahui bahwa ada potensi siswa membawa smartphone ke sekolah. Namun, karena belum adanya fasilitas di sekolah dan media pembelajaran berbasis android yang menggunakan smartphone, maka smartphone yang dibawa siswa tidak digunakan saat pembelajaran termasuk saat pembelajaran matematika. Selain itu, guru menyampaikan bahwa ketika pembelajaran seperti biasa, siswa terlihat kurang tertarik dan kurang bersemangat sehingga siswa kurang berminat untuk belajar.

Informasi yang diperoleh berdasarkan studi pendahuluan dengan wawancara pada guru matematika di SMP Negeri 7 Depok, SMP Fatahillah, dan SMP Muhammadiyah Cisalak, metode yang sering digunakan guru dalam pembelajaran matematika yaitu metode konvensional, sedangkan untuk media yang digunakan hanya media yang disediakan oleh sekolah. Selain itu, semua guru setuju bahwa metode-metode dasar seperti itulah yang mudah dan cocok digunakan dalam kelas untuk pembelajaran matematika. Kemudian sumber belajar yang digunankan adalah buku paket dan buku lembar kerja siswa. Materi yang paling sering diajarkan menggunakan alat peraga adalah materi pada pokok bahasan bangun ruang saja. Untuk nilai yang diperoleh siswa dalam pembelajaran matematika, masih rendah dan di bawah KKM yang ditentukan sekolah.

Sementara itu, dari hasil studi pendahuluan di sekolah pada siswa SMP Negeri 7 Depok, SMP Fatahillah, dan SMP Muhammadiyah Cisalak, kebanyakan dari mereka masih suka bermain dan kurang memperhatikan penjelasan guru terutama dalam penyampaian materi yang terkesan membosankan. Penyampaian guru yang hanya mengandalkan papan tulis dan buku pegangan membuat siswa kurang paham dengan materi yang disampaikan guru. Akibatnya siswa terkadang cenderung malas untuk membaca, mencari dan membeli buku. Oleh karena itu, perlu dibuat sebuah desain pembelajaran yang dapat memudahkan siswa untuk belajar dan mencari materi tanpa harus membeli buku serta dapat dibaca kapanpun dan dimanapun dan tidak berkesan membosankan. Salah satunya media berbasis android, seperti yang disampaikan oleh Juraman (2014) bahwa saat ini banyak masyarakat yang beralih menggunakan perangkat berbasis android untuk dijadikan sebagai media dalam mengakses informasi secara mudah dan cepat.

Berdasarkan permasalahan tersebut, peneliti berkeinginan memilih, menetapkan, mengembangkan metode untuk mencapai hasil pengajaran. Pemilihan, penetapan, dan pengembangan metode ini didasarkan pada situasi kondisi permasalahan yang ada seperti tujuan pembelajaran. Media pembelajaran berbasis android dirasa perlu digunakan mengingat bahwa setiap siswa pasti menginginkan pembelajaran yang efektif, efisien, sekaligus menyenangkan dan sesuai dengan perkembangan kemajuan Ilmu Pengetahuan, Teknologi, dan Seni (IPTEKS). Oleh sebab itu, diperlukan perancangan pembelajaran atau desain pembelajaran yang baik. Sehingga diperlukan langkah nyata dalam membuat desain pembelajaran yang disusun secara baik dan seimbang. Selain itu, dengan desain pembelajaran yang baik dapat membuat pembelajaran menjadi lebih efektif dan efisien. Dalam menjawab permasalahan tersebut perlu dikaji bagaimana mengajarkan matematika khususnya bagi siswa SMP supaya matematika lebih menarik dan mudah untuk di pahami. 


\section{METODE}

Penelitian pengembangan yang dilaksanakan pada semester ganjil tahun pelajaran 2017/2018 ini bertempat di tiga sekolah, yaitu: (1) SMP Negeri 7 Depok, yang terletak di Jalan Radar Auri, Cisalak, Cimanggis, Mekarsari, Kota Depok, Jawa Barat 16452; (2) SMP Fatahillah, yang terletak di Jalan Raya Bogor Km.31 No. 25 Cisalak, Cimanggis, Kota Depok, Jawa Barat 16452; dan (3) SMP Muhammadiyah Cisalak, yang terletak di Jalan Masjid Al-Islah, Cisalak, Sukmajaya, Kota Depok, Jawa Barat 16416. Metode yang digunakan dalam penelitian ini adalah metode penelitian dan pengembangan research and development, Brog and Gall dalam (Tegeh, 2014:7). Untuk dapat mengembangkan media pembelajaran dapat digunakan model desain pembelajaran, ADDIE (Analysis; Design; Development; Implementation; dan Evaluation) yang dipadukan menurut langkah-langkah penelitian pengembangan yang direkomendasikan oleh Brog dan Gall dengan dasar pertimbangan bahwa model tersebut cocok untuk mengembangkan produk model instruksional/pembelajaran yang tepat sasaran, efektif, dinamis dan sangat membantu dalam pengembangan pembelajaran bagi guru.

Model desain instruksional ADDIE (Analysis; Design; Development; Implementation; dan Evaluation) yang dikembangkan oleh Reiser dan Mollenda tahun 1990-an merupakan model design pembelajaran yang bersifat generik menjadi pedoman dalam membangun perangkat infrastruktur program pelatihan yang efektif dinamis, dan mendukung kinerja pelatihan itu sendiri. Sehingga membantu instruktur pelatihan dalam pengelolahan pelatihan dan pembelajaran.

Dalam penelitian ini, teknik pengumpulan data yang dilaksanakan, yaitu: Studi pendahuluan, observasi/wawancara dan angket. Pengumpulan data dalam penelitian ini dilakukan dengan menggunakan instrumen penelitian berupa pedoman wawancara dan angket penilaian media, penilaian materi, serta respons guru, masing-masing dilengkapi dengan rubrik penilaian yang dimodifikasi dari aspek kriteria penilaian media pembelajaran. Teknik analisis data yang digunakan adalah statistik deskriptif kualitatif, dimana setelah data diperoleh, selanjutnya menganalisis data tesebut dengan disajikan dalam bentuk tabel, kemudian diinterpretasikan dengan cara perhitungan frekuensi dan persentase lalu ditafsirkan dengan kalimat sebagai penjelasannya. Stasistik deskriptif kualitatif digunakan untuk menganalisa data dengan cara mendeskripsikan data yang telah terkumpul. Sebagaimana adanya tanpa bermaksud membuat kesimpulan yang berlaku untuk umum atau generalisasi (Sudjiono, 2008).

\section{HASIL PENELITIAN}

Pengembangan media pembelajaran ini sesuai dengan langkah-langkah prosedur penelitian Research and Developmen model ADDIE yang terdiri dari tahap Analysis (Analisis), Design (Desain), Development (Pengembangan), Implementation (Penerapan), dan Evaluation (Evaluasi) yang dimodifikasi oleh peneliti. Kelima tahapan model ADDIE dalam pengembangan media pembelajaran ini dilakukan secara sistematis. Berikut penjelasan tahap-tahap dalam pengembangan media pembelajaran dalam pembelajaran matematika yang sesuai dengan model ADDIE.

1. Penelitian Pendahuluan

Sebelum pengembangan media pembelajaran pada untuk tingkat SMP ini dilakukan, peneliti melakukan penilitian pendahuluan melalui studi kepustakaan, wawancara, dan observasi pada siswa dan guru matematika di SMPN 7 Depok, SMP Fatahillah, dan SMP Muhammadiyah Cisalak Depok. Penelitian dilakukan di tiga sekolah bertujuan untuk mendapatkan hasil yang relevan dan objektif sesuai dengan kebutuhan daripada penelitian ini.

Berdasarkan hasil wawancara dengan guru matematika di SMPN 7 Depok, SMP Fatahillah, dan SMP Muhammadiyah Cisalak Depok, semua guru memiliki jawaban yang hampir sama dalam pemilihan 
metode pembelajaran. Guru di SMP Fatahillah dan SMP Muhammadiyah Cisalak sering menggunakan metode ceramah, diskusi dan latihan. Berbeda halnya guru di SMPN 7 Depok yang pernah melakukan proses pembelajaran dengan media. Metode ceramah yang menggunakan media pembelajaran power point, laptop dan LCD Projector. Guru di SMPN 7 Depok mengungkapkan bahwa siswa sangat tertarik dan antusias terhadap pembelajaran yang menggunakan media tersebut dan mendapatkan hasil belajar yang relatif baik, namun guru juga mengungkapkan bahwa menggunakan media pembelajaran tersebut tidak diterapkan pada semua materi, karena rentan waktu menggunakan metode ceramah dengan media juga terlampau lama dan memakan waktu lebih untuk proses persiapan dan pembelajarannya. Oleh sebab itu, guru di SMPN 7 Depok lebih sering memilih metode ceramah menggunakan buku, papan tulis dan penugasan.

Penelitian pendahuluan di tiga sekolah tersebut hampir memiliki alasan yang sama untuk penggunaan media pembelajaran dalam proses pembelajaran yaitu perlu meluangkan waktu lebih, baik dalam persiapan ataupun proses pembelajarannya. Metode yang dipakai oleh guru saat ini dirasa mudah untuk diaplikasikan dan tanpa memerlukan persiapan yang rumit, selain itu semua guru setuju bahwa metode-metode dasar seperti itulah yang mudah dan cocok digunakan dalam kelas untuk pembelajaran matematika. Materi yang paling sering diajarkan menggunakan alat peraga adalah materi pada pokok bahasan bangun ruang saja. Untuk pokok bahasan lainnya seperti aljabar, bilangan, statistika dan peluang, biasanya siswa hanya diminta untuk mengerjakan soal-soal latihan yang guru berikan

2. Analisis Kebutuhan

Berdasar pada hasil studi pendahuluan berupa hasil wawancara dengan siswa di SMPN 7 Depok, SMP Fatahillah, dan SMP Muhammadiyah Cisalak, siswa di sana mengaku merasa bosan belajar dengan metode belajar yang selama ini diajarkan oleh guru. Seperti yang telah diuraikan oleh peneliti dalam studi pendahuluan, bahwa di tiga sekolah tersebut, guru menyatakan lebih memilih metode pengajaran tanpa media atau alat peraga yang dirasa mudah untuk diaplikasikan dan tanpa memerlukan persiapan yang rumit.

Padahal secara umum siswa masih banyak yang kurang fokus saat belajar dengan metode pembelajaran yang selama ini lebih dominan digunakan oleh guru. Oleh karena itu, dibutuhkan media untuk membantu proses belajar siswa agar siswa tidak mengalami rasa bosan dan kurang fokus pada saat proses pembelajaran matematika, sehingga mampu merangsang kreativitas siswa. Dengan demikian, terdapat hal yang menjadi kebutuhan yang sangat perlu untuk ditingkatkan yaitu mengenai media pembelajaran matematika yang digunakan guru dalam mengajar khususnya pada materi dasar yaitu bilangan. Karena bilangan merupakan materi yang wajib dipahami siswa dan merupakan materi pokok yang menjadi pondasi utama dalam berbagai pengaplikasian materi-materi pada bab-bab selanjutnya. Adapun hasil wawancara dengan siswa di SMPN 7 Depok, siswa di SMP Fatahillah, dan siswa di SMP Muhammadiyah Cisalak, bahwa dalam pembelajaran matematika khususnya pada materi bilangan sebagian besar siswa mengalami kesulitan dan juga merasa bosan dengan pembelajaran yang monoton. Guru di di SMPN 7 Depok, SMP Fatahillah, dan SMP Muhammadiyah Cisalak juga merasakan adanya hambatan pada materi dasar. Sehingga untuk melanjutkan materi ajar, guru harus mengulang materi dari dasar terlebih dahulu dan setelahnya guru harus mengejar materi yang tertinggal akibat harus meluangkan waktu yang lebih banyak dalam pembelajaran untuk mengulang materi dasar.

Berdasarkan kebutuhan, peneliti membuat media pembelajaran untuk membantu guru dan siswa serta orangtua dari siswa dalam pembelajaran matematika khususnya pada materi operasi hitung penjumlahan, pengurangan, perkalian, dan pembagian. Pengembangan media pembelajaran yang berbasis multimedia dapat dijadikan sebagai salah satu alternatif solusi yang dapat menampung kebutuhan orangtua, guru, dan siswa. 
Media pembelajaran kemudian dapat diimplementasikan di sekolah dalam proses pembelajaran dan juga dapat digunakan dirumah sebagai alat belajar latihan pada siswa dalam mempelajari materi operasi hitung. Setelah menetapkan materi yang akan dibuat medianya, selanjutnya peneliti menganalisis karakteristik materi berdasarkan tujuan materi matematika bilangan yang akan dibuatkan medianya serta strategi dan evaluasi pembelajarannya. Karena bilangan sebagai pondasi siswa dalam pembelajaran matematika pada tingkat sekolah menengah pertama, yang mana materinya terdapat dari kelas 7 sampai dengan kelas 9, dengan demikian materi bilangan diambil dari materi kelas 7 sampai kelas 9 tingkat sekolah menengah pertama dengan standar kompetensi, kompetensi dasar dan tujuan pembelajaran yang hanya terkait dengan konsep media yang akan dibuat.

3. Desain Media

Media ini dibuat dengan ide dasar ingin membuat media pembelajaran matematika yang mendidik, berkualitas minimal baik, menarik, dan membuat siswa menjadi bersemangat belajar matematika. Media pembelajaran berhitung memiliki konsep untuk memudahkan kegiatan belajar, khususnya mata pelajaran matematika dengan memanfaatkan kemajuan teknologi berupa smartphone berbasis android yang membuat media pembelajaran menjadi sebuah aplikasi yang dapat diakses di manapun hanya dengan menggunakan smartphone. Materi pembelajarannya dibuat berdasarkan kebutuhan guru dalam mengajar materi dasar bilangan dan materi pada media diambil dari berbagai sumber yaitu beberapa buku paket matematika kelas 7 sampai dengan kelas 9 SMP.

4. Pengembangan Media

Pada tahap ini, kegiatan yang dilakukan adalah memproduksi media pembelajaran matematika berupa media pembelajaran yang membahas materi bilangan kelas 7 sampai dengan kelas 9 SMP. Proses pembuatan media operasi hitung di SMP menggunakan bahan bantuan berupa perangkat lunak (software) yaitu dengan Windows 10, Adobe Photoshop CS6, Construct 2, dan PowerPoint. Dan perangkat pembelajaran yaitu dengan silabus matematika SD, data visual berasal dari pembuatan peneliti dan pencarian di internet dan materi yang dikumpulkan dari buku teks Matematika SMP kelas 7 sampai dengan 9 dan internet.

Setelah mempersiapkan perangkat pengembangan, selanjutnya peneliti memulai proses pembuatan media dengan mempersiapkan data gambar pada media merupakan buatan pribadi peneliti secara manual menggunakan Adobe Photoshop, PowerPoint dan pencarian di internet, hal ini memudahkan peneliti dalam membuat design seperti background, tombol dan keperluan desain media lainnya, serta memudahkan dalam memindahkan desain ke halaman Construct 2. Setelah design sudah berada di halaman Construct 2, peneliti memasukkan materi berupa teks dan gambar ke dalam masing-masing frame pada Construct 2. Berikut adalah tampilan medianya. 


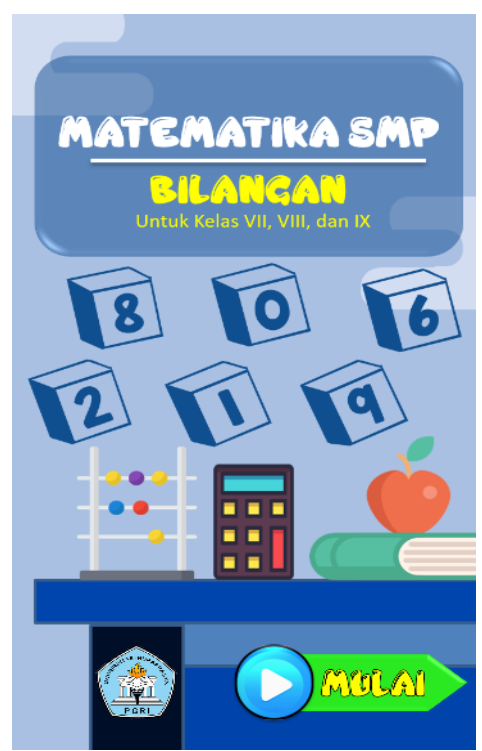

Gambar 1. Tampilan Intro

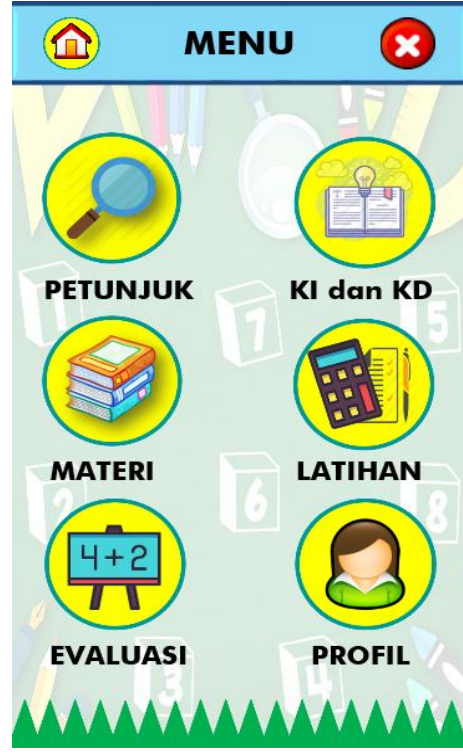

Gambar 2. Menu Utama

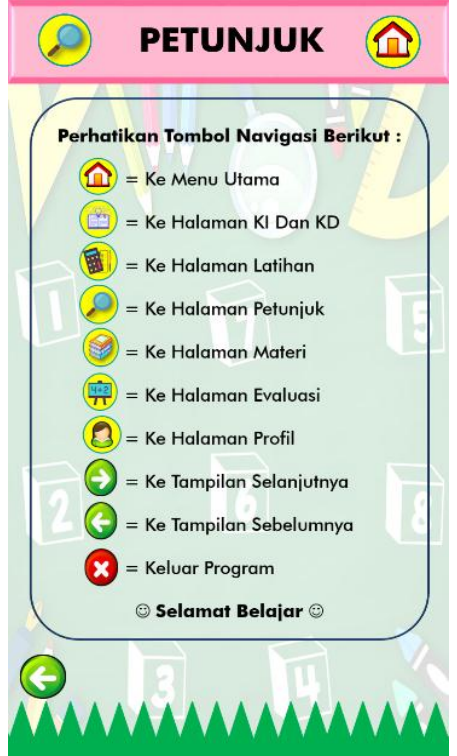

Gambar 3. Petunjuk Penggunaan

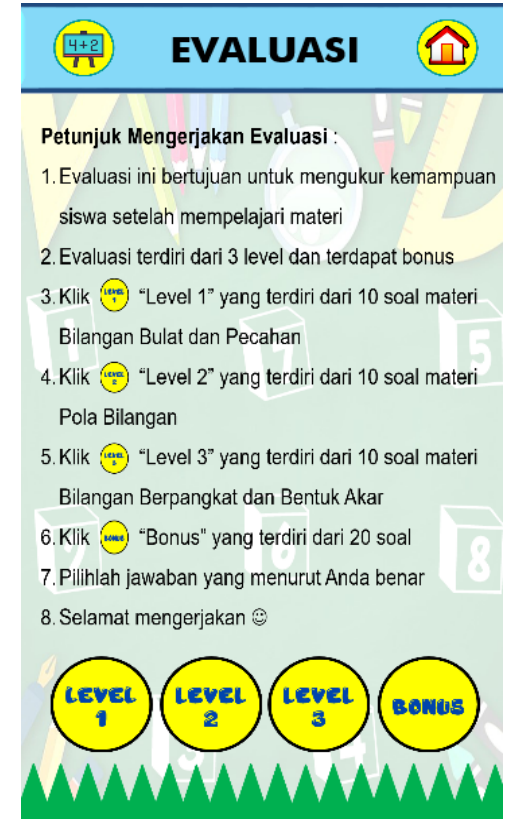

Gambar 4. Petunjuk Evaluasi

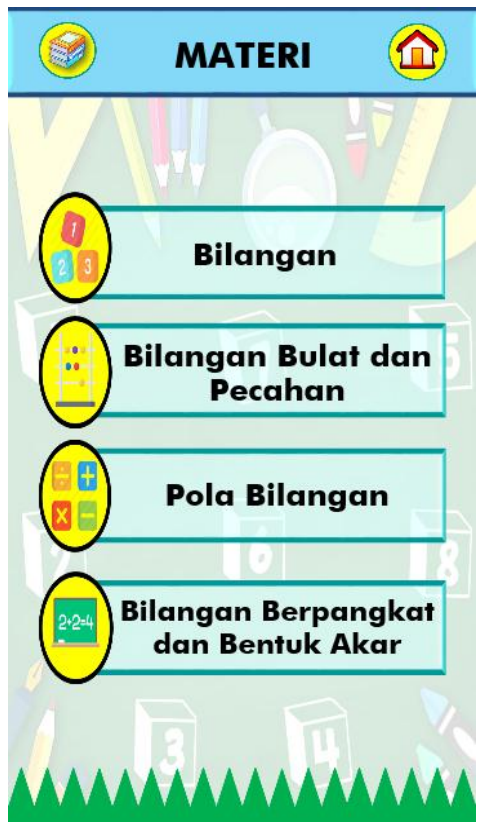

Gambar 5. Sub Materi

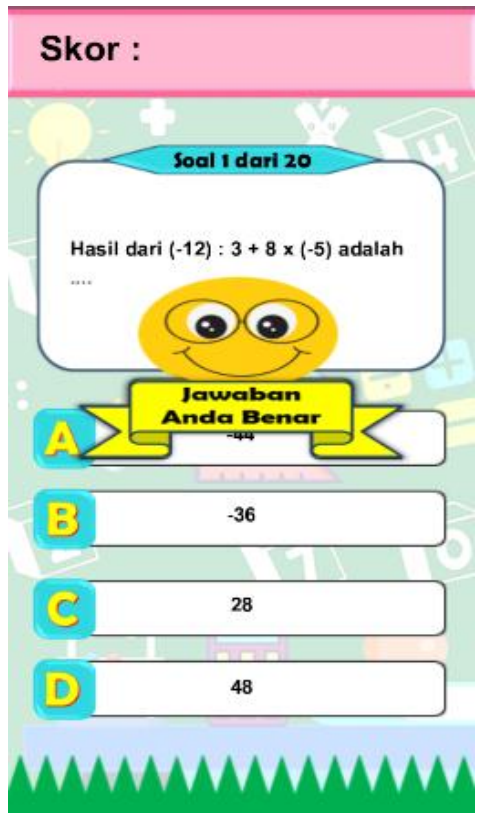

Gambar 7. Soal Evaluasi

\section{Evaluasi Media}

Pada tahap ini, yang dilakukan adalah penilaian media oleh para validator ahli materi, ahli media, dan ahli desain yang ahli di bidangnya untuk menganalisis kelebihan dan kekurangan yang jika ditemukan beberapa kekurangan akan segera dilakukan revisi oleh peneliti. Berdasarkan hasil perhitungan dari para validator, terdapat rata-rata dari setiap ahli, kualitas produk mendapat nilai oleh para ahli materi berupa persentase yaitu sebesar $85,3 \%$, ahli media $80 \%$, dan ahli desain pengembangan 
93\% sehingga dapat dikategorikan sangat baik dan telah memenuhi kualifikasi valid. Dengan kata lain, media yang dikembangkan dalam penelitian ini dinilai layak dan sangat baik untuk digunakan dalam pembelajaran matematika.

\section{PEMBAHASAN}

Media pembelajaran yang dikembangkan berupa aplikasi yang berbasis android. Sehingga media pembelajaran yang dikembangkan dapat dijalankan kapan pun dan dimanapun. Media pembelajaran ini termasuk dalam kategori media pembelajaran berbasis mobile learning. Hal ini sesuai dengan yang definisi mobile learning yang dinyatakan oleh O'Malley (2003:6), yaitu suatu pembelajaran yang pembelajar (learner) tidak diam pada satu tempat atau kegiatan pembelajaran yang terjadi ketika pembelajar memanfaatkan perangkat teknologi bergerak.

Berdasarkan penelitian yang dilakukan oleh Putriani, dkk. (2017) dalam penelitiannya yang berjudul "Pengembangan Media Pembelajaran Berbasis Android Dengan Software Construct 2 Pada Materi Bangun Ruang Sisi Datar Untuk Siswa SMP Kelas 8" penelitian pengembangan ini bertujuan untuk mengembangkan media pembelajaran berbasis android dengan software Construct 2 pada materi bangun ruang yang berkualitas dengan model pengembangan ADDIE (analysis, design, development, implementation, and evaluation) dan menunjukan hasil bahwa karakteristik siswa yang sudah cukup baik namun ada beberapa siswa yang mengalami kesulitan untuk memahami materi yang disampaikan. Hal ini dikarenakan adanya perbedaan kemampuan antar siswa yang satu dengan yang lain. Berdasarkan hasil penilaian media pembelajaran yang dikembangkan termasuk dalam kategori "baik" dengan skor rata-rata keseluruhan 3,98 sehingga media pembelajaran memenuhi aspek kevalidan dengan evaluasi yang telah dilakukan maka diperoleh kesimpulan bahwa media pembelajaran berbasis android dengan software Construct 2 pada materi bangun ruang sisi datar SMP kelas 8 yang berkualitas dari aspek kevalidan, keefektifan, dan kepraktisan. Sehingga peneliti ingin mengembangkan media pembelajaran dengan menggunakan software Construct berbasis android.

Media ini juga memiliki beberapa kelebihan dibanding dengan media pembelajaran yang sudah ada atau sudah digunakan guru pada sekolah yang biasanya hanya berupa powerpoint. Kelebihan pertama adalah media ini menyajikan materi yang dikemas secara singkat dan menarik dengan menampilkan slide pembelajaran interaktif yang berwarna, sehingga membuat siswa lebih antusias, sekaligus lebih bersemangat dalam mengikuti pembelajaran dan memudahkan siswa untuk cepat dalam memahami isi materi tersebut. Tampilan motivasi serta info matematika didalam media ini terbukti mempermudah dan memberikan pengetahuan pelajar dalam suatu pembelajaran.

Selain kemudahan mengoperasikan, kelebihan kedua dari media ini adalah menyampaikan pesan untuk menanamkan pendidikan karakter bagi siswa, dimana ketika siswa atau pengguna memulai latihan soal dalam belajar maupun siswa mengerjakan soal dalam kuis, harus diselesaikan karena tidak disediakan tombol kembali dan apabila aplikasi ditutup pada handphone, setelahnya siswa atau pengguna akan mengakses media, akan kembali ke halaman latihan maupun kuis yang sebelumnya sedang diakses. Pemfokusan, disiplin diri, tanggung jawab, dan komitmen diri dari siswa pada saat menggunakan media ini betul-betul dilatih, sehingga karakter siswa yang menggunakan aplikasi ini menjadi lebih baik dari waktu ke waktu.

Kelebihan yang ketiga dari media ini adalah tidak diberikan "timer atau waktu pengerjaan" pada soal latihan maupun pada soal kuis yang bertujuan agar siswa memiliki waktu untuk menghitung terlebih dahulu secara teliti dan menjawab dengan tepat. Pertimbangan lain untuk tidak memberikan timer dalam media ini adalah agar siswa belajar dan siswa mengerjakan soal latihan juga mengerjakan evaluasi betul-betul dalam keadaan yang santai tanpa terkekang oleh waktu, atau dengan kata lain tanpa tergesa-gesa diburu oleh waktu. 
Walaupun dirasakan terdapat beberapa kelebihan, namun terdapat beberapa keterbatasan dalam pengembangan media ini, yaitu peneliti ini hanya terbatas pada materi yang dikembangkan yaitu terbatas pada materi bilangan. Pada tampilan tes latihan maupun evaluasi dalam media pembelajaran ini hanya berupa pilihan ganda tidak adanya soal essay. Media hanya dapat dioperasikan pada smartphone dengan sistem operasi android karena untuk mengubah file media ke dalam aplikasi yang dapat dioperasikan pada smartphone dengan sistem operasi lain membutuhkan biaya yang cukup mahal. Data yang dikumpukan juga mungkin tidak sesuai dengan teori, karena beberapa peneliti ambil berdasarkan temuan di lapangan seperti pada tahap analisis yaitu wawancara dengan beberapa guru dan siswa, bukan keseluruhan aspek atau skala besar. Keterbatasan dan teknis software media untuk pembuatannya secara teknis belum maksimal karena buku dan pengetahuan yang sangat terbatas saat pembuatan aplikasi tersebut, dan peneliti sebelumnya tidak pernah belajar cara membuat aplikasi atau media sehingga media yang peneliti buat mengalami keterbatasan. Sehingga peneliti hanya sampai pada tahap evaluasi produk tanpa harus ujicoba ke lapangan dengan skala besar. Namun menurut pribadi peneliti sendiri hal tersebut setidaknya sudah mewakili masalah dan potensi yang ada dan sedikit besarnya memberikan alternatif solusi serta menyumbang perubahan yang lebih baik bagi pendidikan.

\section{SIMPULAN}

Penelitian pengembangan berupa mengembangkan media pembelajaran matematika untuk siswa SMP ini bertujuan untuk memberikan gambaran yang menyeluruh tentang bagaimana proses mengembangkan media pembelajaran matematika yang dituangkan sebagai suatu media berupa multimedia interaktif pembelajaran matematika untuk siswa kelas 7 sampai dengan kelas 9 tingkat sekolah menengah pertama dengan pokok bahasan bilangan, bilangan bulat dan pecahan, pola bilangan, dan bilangan berpangkat dan bentuk akar.

Berdasarkan pengembangan media pembelajaran matematika untuk siswa SMP kelas 7 sampai dengan kelas 9 dibuat menggunakan Construct 2, penelitian yang di lakukan merupakan penelitian pengembangan dengan dilakukan melalui lima tahap pengembangan dengan langkah-langkah prosedur penelitian Research and Development model ADDIE yang terdiri dari tahap Analysis (Analisis) ,tahap Design (Desain), tahap Development (Pengembangan), tahap Implementation (Penerapan), dan tahap Evaluation (Evaluasi), menghasilkan produk berupa aplikasi android dengan format apk., kualitas produk mendapat nilai oleh para ahli materi berupa persentase yaitu sebesar $85,3 \%$, ahli media $80 \%$, dan ahli desain pengembangan $93 \%$ sehingga dapat dikategorikan sangat baik dan telah memenuhi kualifikasi valid. Dengan kata lain, media yang dikembangkan dalam penelitian ini dinilai layak dan sangat baik untuk digunakan dalam pembelajaran matematika.

\section{DAFTAR RUJUKAN}

Binangun, H. H., dan Hakim, A. R. (2016). Pengaruh Penggunaan Alat Peraga Jam Sudut terhadap Hasil Belajar Matematika. Jakarta: Jurnal Kajian Pendidikan Matematika. 1(2): 204-214.

Juraman, Stefanus Rodrick. (2014). Pemanfaatan Smartphone Android Oleh Mahasiswa Ilmu Komunikasi dalam Mengakses Informasi Edukatif. Journal Volume III. No.1. Tahun 2014. Sulawesi: Unstrat.

O’Malley, C. dkk. (2003). Guidelines For Learning/Teaching/Tutoring in a Mobile Environtment (Online), (http://www.mobilearn.org/download/results/guidelines.pdf, diakses pada 10 Agustus 2018). 
Putriani, dkk. (2017). Pengembangan Media Pembelajaran Berbasis Android Dengan Software Construct 2 Pada Materi Bangun Ruang Sisi Datar Untuk Siswa SMP Kelas 8. Jurnal Pendidikan Matematika, 3(6): $1-10$.

Rahmawati, E., dan Suhendri, H. (2016). Pengembangan Desain Pembelajaran Matematika Siswa Sekolah Dasar Kelas 6. Jakarta: Jurnal Formatif, 6(3): 184-196.

Sanjaya, Wina. (2010). Strategi Pembelajaran Berorientasi Standar Proses Pendidikan. Jakarta: Kencana Prenada Media Group.

Sudjiono, Anas. (2008). Pengantar Statistika Pendidikan. Jakarta: PT Raja Grafindo.

Suhendri, H. (2011). Pengaruh Kecerdasan Matematika Logis dan Kemandirian Belajar Terhadap Hasil Belajar Matematika. Jurnal Formatif, 1(1): 29-39.

Supardi, U.S. (2013). Hasil Belajar Metematika Siswa Ditinjau Dari Interaksi Formatif Uraian Dan Kecerdasan Emosional. Jurnal formatif, 3(2) : 78-96.

Tegeh, I Made, dkk. (2014). Model Penelitian Pengembangan. Yogyakarta: Graha Ilmu 